\title{
Analytical Study on College Students' View of Love from the Perspective of Contemporary Education
}

\author{
Qi Wang \\ Zhengzhou Vocational University of Information and Technology, Zhengzhou, 450046, China
}

Keywords: education perspective, college students, view of love

\begin{abstract}
This paper will carry out quite detailed survey and analysis of college students' view of love, and believe that current college students have some misunderstandings and one-sidedness in terms of cognition of love and have not prepared well ideologically at all or enough psychological endurance. Thus, we shall view college students' view of love differently from the perspective of modern education, and take scientific, rational and effective educational methods to guide college students to establish correct and positive view of love.
\end{abstract}

\section{Proposal of question}

At present, love phenomenon is quite common on college campus. However, this does not mean that they have correct and feasible view of love, and there are some problems in their view of love in most cases. As a result, there are various conditions during their love, and more seriously, their lives may be endangered, and thus affect campus safety and stability. Therefore, we shall guide college graduates and students to establish correct view of love and love attitude, form good personality, deal with various problems in love correctly, and coordinate the relationship between school learning and love. Therefore, we shall conduct in-depth and detailed analytical study on college students' view of love, carry out targeted guidance and education for their ideological situation and behavioral pattern, educate them to correct incorrect view of love particularly, and avoid secularized or utilitarian love motivation and other unhealthy trends, so that they could control their love attitude and love behaviors well in such an era with extremely rich substances and become useful in the future.

\section{Analysis of current situation of contemporary college students' view of love}

Contemporary college students are basically only children after the "1990s" and have inevitably proud and aloof personality because of superior family environment. Their understanding and thought of love are often strongly individualized. Then, when their love attitude is changed into practical behaviors, it is the process of practicing love. So far, love motivation of contemporary college students mainly includes physiological needs, psychological needs, material needs and family influence etc. While love becomes a common phenomenon among college students, their view of love shows the following characteristics, i.e. concern about virtues of lovers, gradual openness of love behaviors, younger ages, impetuous love attitude, no marriage in love results, significant changes in sex concept, tolerance of breaking up, utilitarian love purpose, and generation of new love ways such as online love affair etc. Therefore, current situation of today's college students' view of love can be reflected from the following aspects:

(1) Love motivation becomes diversified. Currently, college students' view of love shows an increasingly diversified characteristic. Some students pursue the so-called pure love instead of adding too much secular components to love; some just want to accumulate certain love experience during college, and better experience different lifestyles during learning in the youth; some feel desolate and lonely without protection of their parents and families, and want to seek some excitement from love; and some follow the trend blindly when seeing others falling in love, in order to prove their charm.

(2) Moral ideas become increasingly weakened. In this era with extremely rich material life, most college students are only children of their families with superior family conditions, they are 
quite impetuous towards love, and believe that falling in love during learning can enrich life experience, and they could seize the day and get certain spiritual excitement and enjoyment. Some college students just want to fill in blank of learning in campus life, as mere learning would make college life plain and dull, and thus they comfort spiritual emptiness and loneliness through love. Besides, some college students have not clear objectives in love during college, but just fall in love purely without considering about results of love or taking marriage as the ultimate purpose of love, and they care more about previous possession of love instead of everlasting love. Therefore, college students have increasingly weakened moral ideas in terms of love attitude, and unilaterally emphasize their own individual experience and feelings in love without considering about each other's thought, and lead to unhealthy love trend of emphasis on love course instead of results, and would choose to break up once they feel no passion in love.

(3) Love course becomes too simplified. Today's college students are representatives of younger generations, and have active ways of thinking, love to pursue new things, feel sentimental, and have not formed mature and stable outlook on life, world outlook and values. Thus, under such increasingly fast pace of life, their attitude towards love starts to focus on experience of love, lack a necessary sense of ideological constraints, and they believe that love is a type of living and life experience without necessity of too complex love course, and worship a simple one. Actually, such view of love weakens love behaviors of many college students, as they seldom consider about family factors and social background etc in love. Although they attach importance to each others' emotions in love, they are greatly arbitrary and less bound, pursue the so-called love romance blindly, and would separate arbitrarily once there is not any passion or because of work after graduation etc.

(4) Love becomes open and popular. At present, college students will no longer fall in love privately, but believe that love itself is a matter of course, and tend to open their love behaviors. On college campus, students in love can be seen everywhere, and have been a unique scenery line. Besides, with the rapid popularization of internet, many college students will also pursue virtual love besides falling in love in real life, and will often talk about their feelings in virtual network world and try to get each other's information when they have not found appropriate lovers in real life. Moreover, college students think that online love affair is quite private and convenient, and they can chat and interact freely, saving lots of unnecessary troubles and confusion.

\section{Analysis of causes of contemporary college students' view of love}

Current situation of Chinese college students' view of love is analyzed above, and then what are the causes? Through specific analysis, causes of contemporary college students' view of love include the following aspects:

(1) Traditional Chinese cultural concepts have certain influence. The core of traditional Chinese culture is morality orientation, and hopes that love would finally lead to marriage, which is concentrated reflection of traditional Chinese view of marriage and love. As important young groups of today's Chinese society, college students have view of love affected by traditional cultural concepts and influenced subtly by mainstream social culture, lots of them would follow traditional Chinese cultural concepts, and have a quite cautious attitude towards love and relationships, and stress moral quality and ability of lovers. Therefore, it is said that college students' view of love follows traditional cultural concepts unconsciously and consciously to a great degree, emphasizes loyalty and specificity of love, and many college students oppose premarital sex. Although contemporary college students have strong rebellious consciousness and freedom, they still emphasize constraint and guidance of traditional Chinese ethics and morals deep in their hearts.

(2) Western cultures are constantly introduced to China. In living environment of contemporary Chinese college students, Chinese and western cultures are combined together, making students prone to confusion in front of love. In fact, western cultural thoughts and cultural system, which are quite complicated and contradictory, and full of various conflicts and cultural contradictions, especially some unhealthy cultural trends, such as individualism, egoism and money worship etc, are introduced to traditional Chinese cultural system through the policy of reform and opening up. 
In western culture, marriage and love are private affairs that others cannot interfere, and love and marriage do not belong to the range of morals. This forms a sharp contrast with the concept of traditional Chinese culture which believes that love and marriage are carriers of kinship and responsibility. However, some college students will still be influenced by these western cultures, resulting in unhealthy behaviors like weak love relationship etc, weakened emotion and responsibility in love, relative worship of sexual liberation and sexual freedom in western cultures, making college students feel puzzled and confused about love.

(3) Network culture and film \& television culture have impacts. With the launch and popularization of network technology, college students become indispensable members of network world. They feel strongly curious about the network world, and believe that the virtual network world has advantages such as rapid information transmission, wide coverage, high openness and interactivity etc, and thus have strong interest in love in the network world. Actually, the network world has some defects compared with the real one. However, college students as younger generations have not formed mature and stable world outlook and view of love, and perhaps can easily find spiritual comfort and spiritual destination in the virtual network world, such satisfaction of college students' yearning for free love actually brings lots of problems, especially difference and disconnection between their love ideal and practical life. Some unhealthy network culture would also cause negative impacts on college students. In addition, film \& television culture has certain influence on college students' view of love, as some of them are addicted to idol dramas and have too ideal views about love and marriage. Some films describe marriage and love life too contradictorily, making college students have doubts about marriage and love and even unhealthy psychological trend of fear of marriage.

\section{Guide college students to establish correct view of love from the perspective of contemporary education}

There are various conditions of contemporary college students' view of love because of influence and interference of many factors. So, we shall strengthen education and guidance for them, begin with modern educational concepts and take various educational methods to guide them to establish correct view of love.

(1) Teach college students about appropriate time and conditions for love. Specifically, we shall be concerned about college students' psychological characteristics, especially their emotional changes. As younger generations, they have quite unstable emotions, impulsive behaviors and thoughts, and thus lead to unhealthy emotions like puzzles or confusion. Therefore, we shall teach them to establish correct and objective self-awareness as soon as possible, and form quite mature psychological status. Besides, we shall also teach them to have relatively stable outlook on life and world outlook, and have relatively solid knowledge foundation, relatively abundant social experience and independent economic conditions, so as to provide practically effective foundation and guarantee for various good opportunities and conditions of campus love.

(2) Strengthen guidance and counseling for college students' correct view of love. We shall provide counseling and guidance for college students in terms of view of love, fully respect their individualized development, and explain view of love and marriage to them according to their ages and psychological characteristics. In particular, for education related to sex, we shall give extremely important guidance, so that they could have correct view of love during school learning, and participate in various positive and beneficial extracurricular and social activities, distract from curiosity about love and understand that the thought of love is normal and natural. Meanwhile, we shall also carry out positive education for college students, eliminate unhealthy impacts of various negative social factors by building a good campus cultural environment, guide and educate them correctly and positively through various seminars etc. Moreover, we shall also guide contemporary college students to adjust their view of love, i.e. learn to think in love, deal with the relationship between love and learning, and improve moral cultivation of love.

(3) Carry out education about view of love for college students in various ways. That is to say, we shall conduct education of view of love in a variety of ways for college students. Specifically 
speaking, we could teach some correct concepts about love directly to students through ideological and moral cultivation courses. In fact, this is one of the best ways to carry out education of view of love for college students. We shall teach students in accordance with their aptitude according to their actual conditions, strengthen pertinence and effectiveness of education of view of love for students, and guide them to establish correct and scientific view of love. Moreover, we could guide college students' view of love appropriately through various courses like Psychology of College Students, Human Physiology, Literature, and Art etc to cultivate their good moral traits, carry out corresponding psychological counseling activities to help them eliminate psychological problems and barriers during love and optimize their love purpose and behaviors, and conduct relevant theme activities so that they could grow in love and improve life quality and learning effects through love.

\section{Acknowledgments}

This paper is supported by Humanities and Social Sciences Research Project of the Education Department of Hunan Province, name: Study on Current Situation and Countermeasures of Contemporary College Students’ Love, No.: 2014-gh-654.

\section{References:}

[1] Feng Xiaoxing. Marriage Problems and Education of College Students [J]. Journal of Shanxi College for Youth Administrators, 2001(3)

[2] Li Bei. On Education of College Students' View of Love [J]. Journal of Hunan Financial and Economic College, 2001(1)

[3] Li Zhongduan. Several Thoughts on College Students' Love [J]. Journal of Social Science of Jiamusi University, 2001(6)

[4] Lu Da, Cui Yanli. Analysis of Contemporary College Students' View of Love [J]. Journal of Yanan College of Education, 2002(1)

[5] Tang Dianqiang, Wang Suran. A Statistic Analysis of the Students Who Have Love Affair in Teachers Colleges and Universities [J]. Journal of Hebei Normal University (Educational Science Edition), 2001(3) 